\title{
Stereological Assessment of Nephroprotective Effects of Trachyspermum ammi Essential Oil against Carbon Tetrachloride-Induced Nephrotoxicity in Mice
}

\author{
Evaluación Estereológica de los Efectos Nefroprotectores del Aceite Esencial de Trachyspermum \\ ammi Contra la Nefrotoxicidad Inducida por Tetracloruro de Carbono en Ratones
}

\author{
Mohammad Hossein Farzaei ${ }^{1}$; Mohammad Mahdi Zangeneh ${ }^{1,2}$; Nader Goodarzi ${ }^{3}$ \& Akram Zangeneh ${ }^{1,2}$
}

FARZAEI, M. H.; ZANGENEH, M. M.; GOODARZI, N. \& ZANGENEH, A. Stereological assessment of nephroprotective effects of Trachyspermum ammi essential oil against carbon tetrachloride-induced nephrotoxicity in mice. Int. J. Morphol., 36(2):750-757, 2018.

SUMMARY: Trachyspermum ammi (T. ammi) has been used in folk medicine as anti-inflammatory, antipyretic, antibacterial, antifungal agent. The present study was conducted to investigate the protective effect of Trachyspermum ammi (T. ammi) essential oil against $\mathrm{CC}_{4-}$ induced nephrotoxicity in mice. Thirty-five mice were divided into five groups as follows; positive control received olive oil $1 \mathrm{~mL} /$ $\mathrm{kg} / \mathrm{ip}$, negative control received $\mathrm{CC} 1_{4} 1 \mathrm{mg} / \mathrm{kg} / \mathrm{ip}+0.5 \mathrm{~mL}$ distilled water orally and tree treatment groups which received $\mathrm{CC} 1_{4}$ similar to the negative control and 200, 800 and $1600 \mu \mathrm{g} / \mathrm{kg}$ of $T$. ammi essential oil, respectively. All treatments were done twice a week (Saturday and Wednesday) for 45 days. On the last day, blood was sampled for urea and creatinine assessment and the left kidney was removed for stereological estimations. Essential oil of $T$. ammi at high dose significantly ( $\mathrm{p} \leq 0.05)$ decreased serum levels of creatinine and urea in comparison with $\mathrm{CC}_{4}$-treated group. Total volume of the kidney, cortex, proximal convoluted tubules (PC), glomerulus, vessels and interstitial tissue as well as total length of $\mathrm{PC}$ and vessel were significantly ( $\mathrm{p} \leq 0.05$ ) increased following $\mathrm{CC}_{4}$ administration and were restored toward normal levels at high dose of $T$. ammi. Also, high dose of T. ammi improved glomerular loss significantly (p $\leq 0.05$ ) as compared with $\mathrm{CCl}_{4}$-treated group. Due to the chemical composition of $T$. ammi essential oil such as tymol, $p$-cymene, $\gamma$-terpinene which are antioxidant, it can be concluded that the essential oil of $T$. ammi can ameliorated renal injury induced following $\mathrm{CC} 1_{4}$ toxicity via its antioxidant components.

KEY WORDS: Trachyspermum ammi; Carbon tetrachloride; Essential oil; Stereology; Kidney.

\section{INTRODUCTION}

The kidneys participate in adjustment of endocrine system, blood pressure, osmolality situation, reabsorption of vital micronutrients, extracellular fluid volume, wholebody homeostasis, acid-base balance, electrolyte concentrations, and excretion of wastes (Musabayane, 2012). Some of the renal disorders such as glomerulonephritis, interstitial nephritis are mainly caused by toxic chemicals. Carbon tetrachloride is a toxic chemical that can cause damage to many tissues including kidney through free radicals generation and lipid peroxidation (Rechnagel et al., 1989; Kumar et al., 2005; Khan \& Ahmed, 2006; Masuda, 2006). It seems that free radicals- induced lipid peroxidation to be one of the major causes of cell membrane damage resulting in a series of pathological situations by causing acute and chronic renal injuries (Satyanarayana et al., 2001;
Manna et al., 2006; Adewole et al., 2007). Furthermore, there are many reports of documented case studies which indicate that $\mathrm{CC1}_{4}$ can produces renal diseases through alteration of antioxidant status in humans (Javier Perez et al., 1987; Manna et al.). Therefore, in the present study, the $\mathrm{CC}_{4}$ has been used to induce acute nephrotoxicity.

Recently, medicinal plants as a source of useful chemical compounds received much attention for treatment of many diseases and promotion of human health (Zangeneh et al., 2016). Due to recent developments in methodology, medicinal herbs prepared and examined in various types such as essential oils (Tahvilian et al., 2016). Essential oil is a condensed hydrophobic liquid including aromatic compounds from herbs. Essential oils could be extracted

\footnotetext{
${ }^{1}$ Pharmaceutical Sciences ResearchCenter, Faculty of Pharmacy, Kermanshah University of Medical Sciences, Kermanshah, Iran.

${ }^{2}$ Student of D.V.M, Faculty of Veterinary Medicine, Razi University, Kermanshah, Iran.

${ }^{3}$ Department of Basic and Pathobiological Sciences, Faculty of Veterinary Medicine, Razi University, Kermanshah, Iran.
} 
from several parts like leaves, stems, flowers, and roots (Faramarzi et al., 2017). Essential oils can act as antioxidant and anti-inflammatory agents through inhibiting lipid proxidation, scavenging free radicals and chelating metal ions. However, part of plant used, climatic condition and time of harvesting may contribute to their chemical composition and consequently their chemical activities (Miguel, 2010).

Trachyspermum ammi (T. ammi) commonly known as Ajowan caraway, is a wild bush that is widely distributed in Iran and India (Wadikar \& Premavalli, 2012). It contains many substances which can act together to prevent several diseases. T. ammi genus's anti-oxidative and antiinflammatory properties make it a logical adjuvant to improve wound healing (Thangam \& Dhananjayan, 2003; Bera et al., 2004). Based on the literatures, T. ammi has been used in folk medicine as an anti-inflammatory, antipyretic, antibacterial, anti-fungal, antiviral, anti-diabetic, antinociceptive, and analgesic agent (Dashti-Rahmatabadi et al., 2007; Rasooli et al., 2008; Hejazian et al., 2008).

As far as we know, there is a very little data about chemical composition and nephroprotective properties of $T$. ammi essential oil grows in Kermanshah province, west of Iran. Hence, the aim of the present study was to specify the chemical composition of T. ammi essential oil obtained from Kermanshah city, west of Iran and also to investigate its nephroprotective effects against $\mathrm{CC}_{4}$-induced nephrotoxicity. Histological change such as volume and length of renal tubules and glomerular number were estimated stereologically. Renal function was assessed thorough analysis of serum biomarkers.

\section{MATERIAL AND METHOD}

Plant sample collection. In the empirical-experimental study, medicine plant collected from Kermanshah city, west of Iran.

Table I. The components of T. ammi Essential oil that analyzed by GC/MS.

\begin{tabular}{llcc}
\hline No & Compound & Area $(\%)$ & RI (Retention Index) \\
\hline 1 & --Thujene & 0.6 & 927 \\
2 & --Pinene & 0.3 & 934 \\
3 & --Pinene & 1.8 & 976 \\
4 & --Myrcene & 0.6 & 990 \\
5 & $p$-Cymene & 25.7 & 1029 \\
6 & $\gamma$-Terpinene & 25.1 & 1064 \\
7 & Thymol & 44.2 & 1299 \\
8 & Carvacrol & 0.3 & 1302 \\
& Total & 98.6 & \\
\hline
\end{tabular}

Essential oil extraction. Essential oil from aerial part of $T$. ammi extracted by Clevenger apparatus. Briefly, in first 100 to $150 \mathrm{~g}$ of plant was add to the distillation flask (1L) which was join to a steam producer via a glass tube and to a condenser to resume the essential oil in a funnel tube. Components of the essential oil was purified from the plant material and evaporated into hot steam without burning the plant material itself. Then, steam containing the essential oil was compressed through a cooling system for $3 \mathrm{~h}$ and essential oil was withdrawn. The essential oil was purged through anhydrous $\mathrm{Na}_{2} \mathrm{SO}_{4}$ to dehumidified essential oil. Then, the essential oil was accumulated in small and dull vials and stored in a refrigerator.

Gas chromatography / mass spectrometry (GC/MS). GC/ MS (Shimadzu capillary GC-quadrupole MS system QP 5000 (with two fused silica capillary column DB-5 ( $30 \mu \mathrm{m}, 0.25$ $\mu \mathrm{m}$ i.d, film thickness $0.25 \mathrm{~mm}$ ) and a flame ionization detector (FID) run in EI mode at $70 \mathrm{eV}$ were used. Here on, injector temperature was $220{ }^{\circ} \mathrm{C}$ and detector temperature was set at $250^{\circ} \mathrm{C}$. Also in the device, helium was employed as carrier gas $(1 \mu \mathrm{l} / \mathrm{min}) .1 \mathrm{ml}$ of the essential oil was injected and analyzed with the column held initially at $60^{\circ} \mathrm{C}$ for $2 \mathrm{~min}$. Then, the amount of components of the essential oil is obtained. NIST standard reference database (AMDIA version 2.70) was used to interpret the mass spectral data. The constituents of essential oil is present in Table I.

Animals and treatments. Thirty five healthy male Balb/c mice weighing between 30 and $40 \mathrm{~g}$ were provided by laboratory animal center of Kermanshah University of Medical Sciences. The animals were kept under constant humidity and temperature. All animals were allowed free access to food and water ad libitum during the experiment. The animals were treated according to the standard directive as recommended in the Guide for Care and Use of Laboratory Animals and approved by the research authorities of Kermanshah University of Medical Sciences. The mice were divided randomly into five groups $(n=7)$ :

Group I (control): received $1 \mathrm{~mL} / \mathrm{kg}$ olive oil intraperitoneally and $0.5 \mathrm{~mL}$ distilled water through gavages.

Group II: received $1 \mathrm{mg} / \mathrm{kg} \mathrm{CC1}{ }_{4}$ mixed with olive oil in the ratio of 5:5, intraperitoneally $+0.5 \mathrm{~mL}$ distilled water through gavages.

Group III: received $\mathrm{CC}_{4}$ mixed with olive oil in the ratio of 5:5, intraperitoneally + ethanolic extract of T. ammi $200 \mu \mathrm{g} / \mathrm{kg}$ through gavages.

Group IV: received $\mathrm{CC}_{4}$ mixed with olive oil in the ratio of $5: 5$, intraperitoneally + ethanolic extract of T. ammi $800 \mu \mathrm{g} / \mathrm{kg}$ through gavages. 
Group V: received $\mathrm{CCl}_{4}$ mixed with olive oil in the ratio of 5:5, intraperitoneally + ethanolic extract of T. ammi 1600 $\mu \mathrm{g} / \mathrm{kg}$ through gavages.

All treatments were done twice a week (Saturday and Wednesday) for 45 days. On the last day of the experiment, blood samples were obtained from animal's heart and centrifuged for collecting serum. Then the subjects weighed and sacrificed using chloroform inhalation. The left kidney of each animal was removed, weighed and fixed in $10 \%$ neutral buffered formaldehyde. Tubular length estimation needs isotropic uniform random sections. Therefore, after $72 \mathrm{~h}$ fixation, the kidneys were cut using orientator method. Totally, 7-10 slabs were collected from each kidney. The slabs were embedded in paraffin and sections $(5 \mu \mathrm{m}$ thicknesses) were prepared and stained by Periodic Acid Schiff (PAS) method.

Due to the tissue shrinkage following fixation and tissue processing, this should be considered for estimating reference volume. A circle was punched by a trocar from a kidney slab and its area was calculated before $(\mathrm{AB})$ and after (AA) tissue processing. Finally, the tissue shrinkage was estimated using following formula (Nyengaard, 1999):

$$
\text { Volume shrinkage }:=1-\left(\frac{\mathrm{AA}}{\mathrm{AB}}\right)^{1.5}
$$

Total volume of kidney (reference volume) was estimated using:

$$
\mathrm{V}_{\text {final }}:=\mathrm{V}_{\text {primary }} \times(1-\text { volume shrinkage })
$$

\section{Stereological study}

Volume estimation. Each sampled section was analyzed using a videomicroscopy system equipped with a microscope (Olympus CX2, Japan) linked to a video camera (Dinocapture ver.5, dino-lit.com $30.5 \mathrm{~mm}$ ), a P4 PC computer, and a flat monitor to determine the parameters. The point probe (composed of 20 points) was superimposed upon the images of the tissue sections viewed on the monitor, and a volume density $\left(\mathrm{V}_{\mathrm{v}}\right)$ of renal cortex, medulla, glomeruli (GLOM), proximal convoluted tubule (PC), distal convoluted tubule (DC), collecting ducts (CD), Henle's loop $(\mathrm{LH})$, vessels $(\mathrm{V})$, and interstitial tissue (IT) were estimated using point-counting method and the following formula (Fig. 1) (Gundersen et al., 1988):

$$
V_{v}:=\frac{\mathrm{P}_{\text {structure }}}{\mathrm{P}_{\text {reference }}}
$$

Where " $P_{\text {structure }}$ and $P_{\text {reference }}$ " were the number of test points falling on the structure's profile and on the reference space, respectively. 10-14 microscopic fields were examined in each kidney. The absolute volume of the parameters was estimated by multiplying the fractional volume by the final volume of the kidney to prevent the reference trap (Nyengaard; Mandarim-de-Lacerda, 2003).

Length estimation. The length density of the renal tubules and vessels, was estimated using an unbiased counting frame $(740 \times 740 \mu \mathrm{m})($ Nyengaard; Mandarim-de-Lacerda). The counting frame was superimposed on the monitor live images and tubule profiles completely inside the counting frame or partly inside the counting frame but only touching the top and right lines were counted. The length density $\left(\mathrm{L}_{\mathrm{v}}\right)$ of the each tubule was calculated as:

$$
L_{v}:=2 \times \frac{\sum \mathrm{Q}}{a(\text { frame }) \times \sum \text { frame }}
$$

Where $\Sigma \mathrm{Q}$ denotes the total number of the tubule profiles counted per mouse kidney, a(frame) equals the area associated with a frame, $547600 \mu \mathrm{m}^{2}$, and $\Sigma$ is the total number of frames counted. Finally, the total length of each tubule, $L$, was calculated by multiplying the length density $\left(\mathrm{L}_{\mathrm{v}}\right)$ by the final volume of the kidney (Fig. 2).

Number estimation. Total number of glomeruli per kidney was estimated using physical dissector method. From each kidney, section pair $20 \mu \mathrm{m}$ apart (the first and fifth sections) was obtained. Two separate projecting systems with similar equipment were used. Two dissector probe $(740 \times 740 \mu \mathrm{m})$ with exclusion lines (the left and lower margins) and inclusion lines (the right and upper margins) were superimposed on the images of the first section as reference section (Fig. 3a) and fifth section as look-up section (Fig. $3 \mathrm{~b}$ ) at the total magnification 135x. A glomerulus was counted if it was presented in the reference section but not in the look up section and didn't touch the exclusion lines. At least 100 glomeruli per kidney were counted. The numerical density of the glomeruli was estimated using:

$$
\mathrm{N}_{\mathrm{V}}:=\frac{\sum \mathrm{Q}^{-}}{a(\text { frame }) \times \mathrm{h} \times \sum \mathrm{P}}
$$

Where $\Sigma Q^{-}$denotes the number of counted glomeruli, $a$ (frame) is the area of the dissector frame, $\Sigma \mathrm{P}$ is the sum of studied field and $h$ is the dissector height. Total glomerular number was estimated by multiplying the numerical density $\left(\mathrm{N}_{\mathrm{v}}\right)$ by the reference volume (renal cortex). 


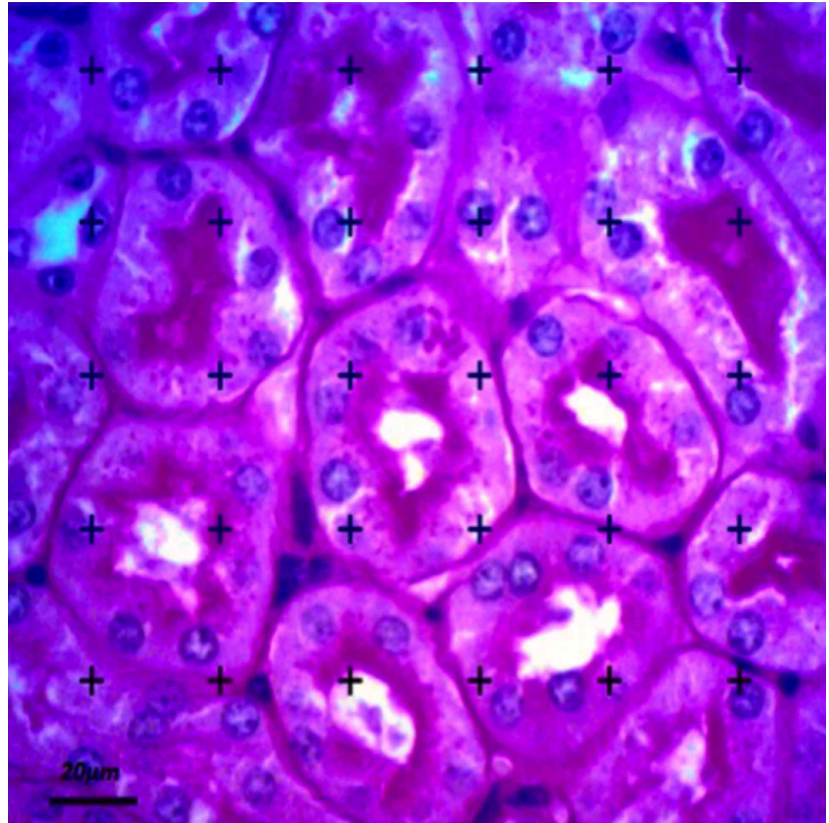

Fig. 1. Estimation of volume density using a point probe. The sum of points hitting each component in 15 microscopic fields was divided by the sum of points hitting the reference space (PAS, 400x).

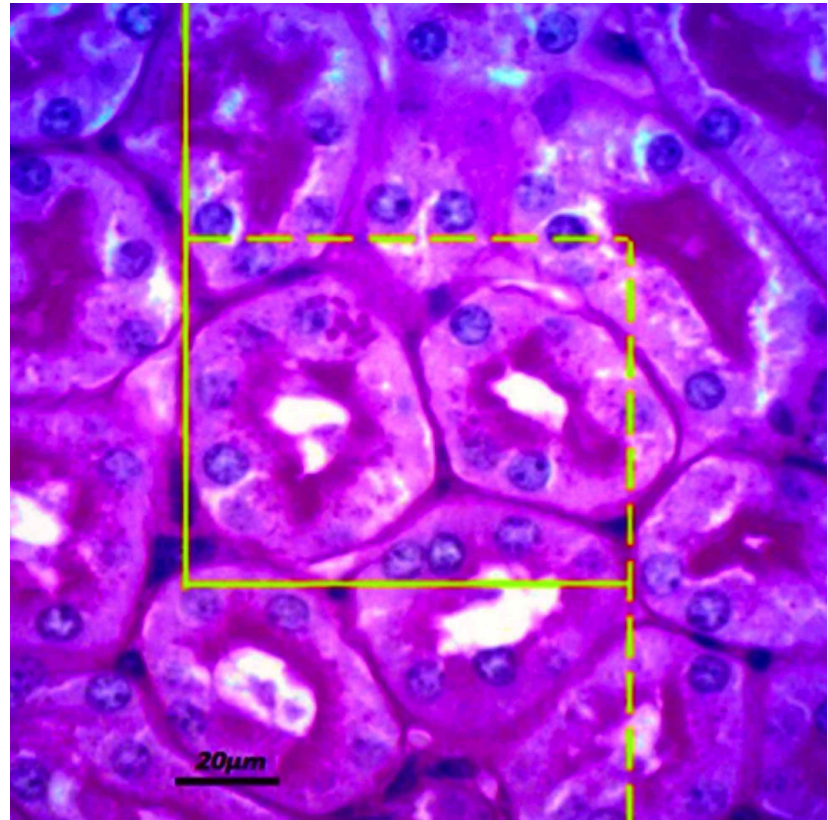

Fig. 2. Estimation of length density of the renal tubules using a counting probe. The tubule structures completely or partly inside the counting frame but only touching the top and right lines are considered (here four proximal convoluted tubules) (PAS, 400x).
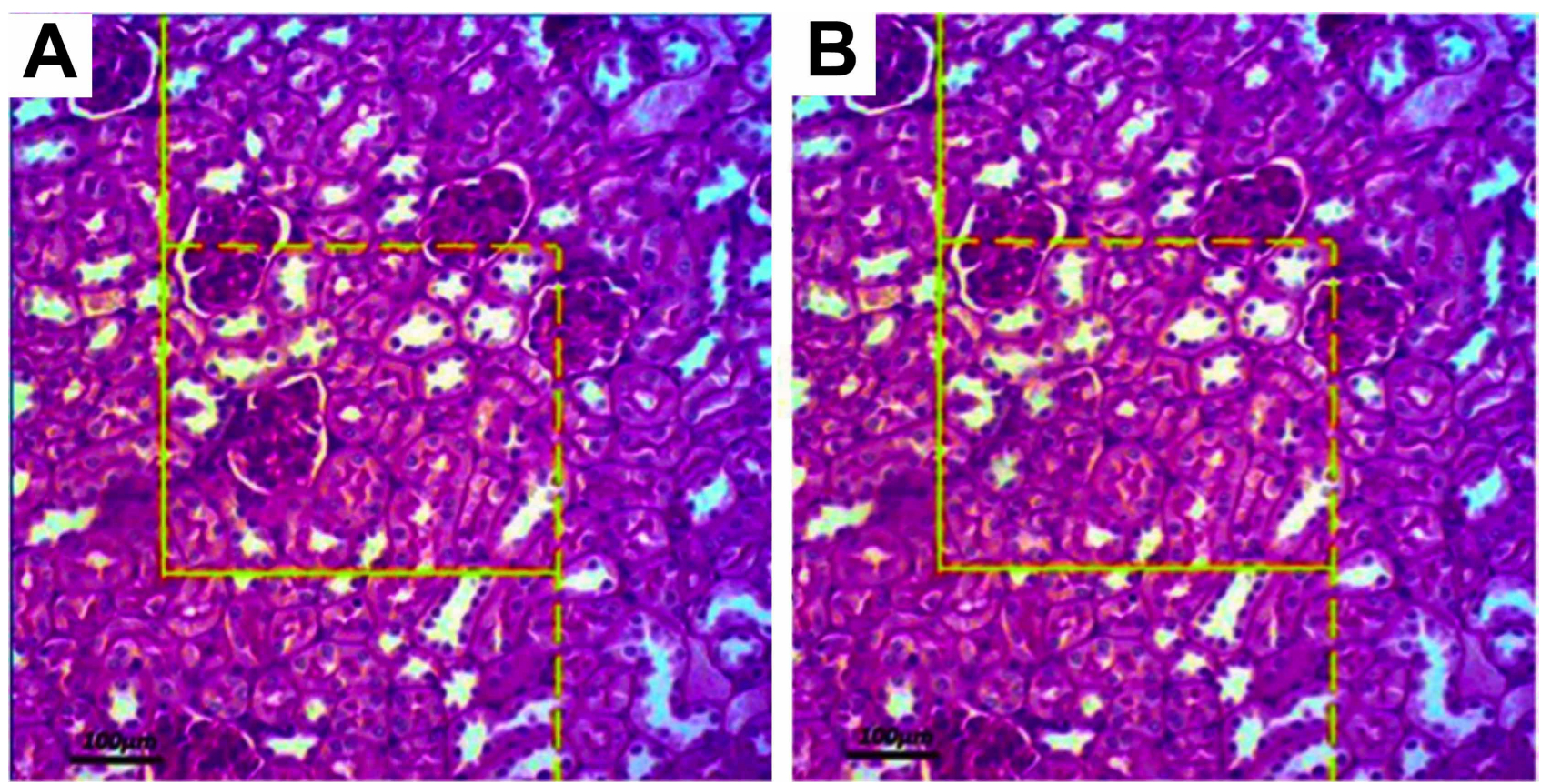

Fig. 3. Physical dissector method and estimation of numerical density of glomeruli. A first section as reference plane and $\mathrm{b}$ fifth section as look-up plane with $20 \mu \mathrm{m}$ distance. A glomerulus was counted if it was located completely or partly in the frame and was not hit by exclusion (continuous) lines in the reference plane as well as if it was not seen in the look-up plane (here 1) (PAS, 100x).

Statistical analysis. All data are expressed as mean and standard deviation. Statistical comparison between group means were done through one-way ANOVA followed by Tukey's post-hoc test. $\mathrm{P} \leq 0.05$ was considered as significant. 


\section{RESULTS}

Chemical composition of T. ammi via GC/MS. Chemical composition of T. ammi essential oil is presented in Table I. The main constituents of T. ammi essential oil are Tymol (44.2\%), p-Cymene (25.7\%) and g-Terpinene $(25.1 \%)$ and $\beta$-Pinene $(1.8 \%)$. Other compounds including aThujene, a-Pinene, b-Myrcene and Carvacrol were found to be less than $1 \%$ of the oil.

Effects of $\mathrm{CCl} 4$ and T. ammi on the weight and volume. The data of the kidney weight, mean absolute volume of kidney and its subcomponents in control and treated groups are shown in Tables II, III and IV. The results showed that the kidney weight and volume were increased $44 \%$ and
$55 \%(\mathrm{p} \leq 0.001)$ respectively in - treated mice in comparison with the control group. Volume of the cortex increased $62 \%(\mathrm{p} \leq 0.001)$ in this group but the medulla increased $40 \%$ which was not significant $(\mathrm{p}>0.05)$ compared to the control group. Treatment of - treated mice with high dose $(1600 \mu \mathrm{g} / \mathrm{kg}$ ) of T. ammi significantly (p $\leq$ 0.05 ) improved the kidney weight and consequently kidney volume in comparison with low and moderate dose (200 and $800 \mu \mathrm{g} / \mathrm{kg}$ ). Further, the volume of the cortex was decreased significantly $(\mathrm{p} \leq 0.05)$ in group which received high dose compared to the - treated group, whereas, medulla volume shows no significant decrease $(\mathrm{p}>0.05)$.

Table II. The kidney weight ( $\mathrm{mg})$, absolute volume of the kidney $\left(\mathrm{mm}^{3}\right)$, and absolute volume $\left(\mathrm{mm}^{3}\right)$ of cortex and medulla of the control and experimental groups treated with $T$. ammi essential oil. Results are given as means \pm standard deviation.

\begin{tabular}{lcccr}
\hline $\begin{array}{l}\text { Groups } \\
(n=7)\end{array}$ & Kidney weight & Kidney volume & Cortex volume & Medulla volume \\
\hline Control & $135.2 \pm 1.4$ & $110.5 \pm 2.9$ & $77.77 \pm 4.3$ & $25.3 \pm 3.2$ \\
$\mathrm{CCl}_{4}$ & $195 \pm 15.6^{*}$ & $171 \pm 21.5^{*}$ & $125 \pm 11.8^{*}$ & $30.9 \pm 13.7$ \\
$200 \mathrm{~T}+\mathrm{CCl}_{4}$ & $191 \pm 18^{*}$ & $160 \pm 14.7^{*}$ & $125.2 \pm 8.6^{*}$ & $30.6 \pm 5.8$ \\
$800 \mathrm{~T}+\mathrm{CCl}_{4}$ & $184 \pm 22.5^{*}$ & $151 \pm 11.8^{*}$ & $123 \pm 12^{*}$ & $28 \pm 7.2$ \\
$1600 \mathrm{~T}+\mathrm{CCl}_{4}$ & $153 \pm 35^{* *}$ & $125.8 \pm 17^{* *}$ & $101.2 \pm 14^{* *}$ & $24.6 \pm 4.3$ \\
\hline
\end{tabular}

$* \mathrm{p} \leq 0.05$ v.s control group. $* * \mathrm{p} \leq 0.05$ v.s CCl4treated group

Table III. Absolute volume $\left(\mathrm{mm}^{3}\right)$ of the proximal and distal convoluted tubules (PCT, DCT), collecting ducts (CD), loop of Henle (LH), vessels (VES) and interstitial tissues (IT) in the control and experimental groups treated with $T$. ammi essential oil. Results are given as means \pm standard deviation.

\begin{tabular}{lcccccc}
\hline $\begin{array}{l}\text { Groups } \\
(n=7)\end{array}$ & PC & DC & CD & LH & VES & IT \\
\hline Control & $68.5 \pm 4$ & $16.5 \pm 3$ & $20.9 \pm 4$ & $1.2 \pm 0.4$ & $6.1 \pm 1.2$ & $11.4 \pm 2$ \\
$\mathrm{CCl}_{4}$ & $122.2 \pm 12^{*}$ & $22.5 \pm 5.7$ & $25.4 \pm 5.1$ & $1.36 \pm 0.65$ & $11.2 \pm 4.2^{*}$ & $18.7 \pm 4.5^{*}$ \\
$200 \mathrm{~T}+\mathrm{CCl}_{4}$ & $115 \pm 18$ & $20.1 \pm 5.1$ & $21.2 \pm 6.3$ & $1.2 \pm 0.3$ & $11.8 \pm 3.5^{*}$ & $19.5 \pm 2.2^{*}$ \\
$800 \mathrm{~T}+\mathrm{CCl}_{4}$ & $112.8 \pm 8.9^{* *}$ & $17.5 \pm 2.8$ & $23.7 \pm 3.4$ & $1.25 \pm 0.26$ & $9.8 \pm 2.9^{*}$ & $16.1 \pm 5.1^{*}$ \\
$1600 \mathrm{~T}+\mathrm{CCl}_{4}$ & $88 \pm 13^{* *}$ & $14.8 \pm 3.1$ & $21.7 \pm 5.2$ & $1.17 \pm 0.38$ & $7.5 \pm 1.8^{* *}$ & $12.4 \pm 3^{* *}$ \\
\hline
\end{tabular}

$* \mathrm{p} \leq 0.05$ v.s control group ** $\mathrm{p} \leq 0.05$ v.s $\mathrm{CCl}_{4}$ treated group

Table IV. Absolute volume $\left(\mathrm{mm}^{3}\right)$ and number of the glomeruli (GLOM) in the control and experimental groups treated with $T$. ammi essential oil. Results are given as means \pm standard deviation.

\begin{tabular}{llc}
\hline $\begin{array}{l}\text { Groups } \\
(n=7)\end{array}$ & $\begin{array}{l}\text { Parameters } \\
\text { Volume }\end{array}$ & Number \\
\hline Control & $0.002 \pm 0.0001$ & $28990.4 \pm 1851.5$ \\
$\mathrm{CCl}_{4}$ & $0.005 \pm 0.0003^{*}$ & $22474.8 \pm 856.3^{*}$ \\
$200 \mathrm{~T}+\mathrm{CCl}_{4}$ & $0.004 \pm 0.0001^{*}$ & $22675 \pm 1055$ \\
$800 \mathrm{~T}+\mathrm{CCl}_{4}$ & $0.004 \pm 0.0002^{*}$ & $23556 \pm 1168^{* *}$ \\
$1600 \mathrm{~T}+\mathrm{CCl}_{4}$ & $0.002 \pm 0.0002^{* *}$ & $26881 \pm 1014^{* *}$ \\
\hline
\end{tabular}

$* \mathrm{p} \leq 0.05$ v.s control group. $* * \mathrm{p} \leq 0.05$ v.s $\mathrm{CCl}_{4}$ treated group. 
Table V. Absolute length (m) of the proximal and distal convoluted tubules (PCT, DCT), collecting ducts (CD), loop of Henle (LH) and vessels (VES) in the control and experimental groups treated with T. ammi essential oil. Results are given as means \pm standard deviation.

\begin{tabular}{|c|c|c|c|c|c|}
\hline \multirow{2}{*}{$\begin{array}{l}\text { Groups } \\
(n=7)\end{array}$} & \multicolumn{5}{|c|}{ Parameters } \\
\hline & $\mathrm{PC}$ & DCT & $\mathrm{CD}$ & LH & VES \\
\hline Control & $33.8 \pm 5.7$ & $23 \pm 3.3$ & $42.3 \pm 5.7$ & $19.5 \pm 4.4$ & $56.6 \pm 11.7$ \\
\hline $\mathrm{CCl}_{4}$ & $51.2 \pm 9.1$ & $32 \pm 5.4$ & $51.1 \pm 6.6$ & $22.3 \pm 4.3$ & $82 \pm 13.3^{*}$ \\
\hline $200 \mathrm{~T}+\mathrm{CCl}_{4}$ & $49 \pm 7.7^{*}$ & $28 \pm 2.5$ & $49 \pm 5.2$ & $21.4 \pm 4.5$ & $80 \pm 8.6^{*}$ \\
\hline $800 \mathrm{~T}+\mathrm{CCl}_{4}$ & $44.4 \pm 6.5^{*}$ & $29 \pm 3.8$ & $52 \pm 10.5$ & $20.2 \pm 3.9$ & $75.8 \pm 11.2 *$ \\
\hline $1600 \mathrm{~T}+\mathrm{CCl}_{4}$ & $32.5 \pm 4.1 * *$ & $27.5 \pm 6.8$ & $46.1 \pm 7.4$ & $19.8 \pm 3.1$ & $61.2 \pm 7.7 * *$ \\
\hline
\end{tabular}

$* \mathrm{p} \leq 0.05$ v.s control group. $* * \mathrm{p} \leq 0.05$ v.s $\mathrm{CCl} 4$ treated group 11

Table VI. Serum profile parameters in the control and experimental groups treated with T. ammi essential oil. Results are given as means \pm standard deviation.

\begin{tabular}{lcc}
\hline $\begin{array}{l}\text { Groups } \\
(n=7)\end{array}$ & $\begin{array}{c}\text { Parameters }(\mathrm{mg} / \mathrm{dl}) \\
\text { Urea }\end{array}$ & Creatinine \\
\hline Control & $30 \pm 3.4$ & $0.26 \pm 0.05$ \\
$\mathrm{CCl}_{4}$ & $43.25 \pm 3.7^{*}$ & $0.37 \pm 0.05^{*}$ \\
$200 \mathrm{~T}+\mathrm{CCl}_{4}$ & $33.5 \pm 1^{* *}$ & $0.22 \pm 0.05^{* *}$ \\
$800 \mathrm{~T}+\mathrm{CCl}_{4}$ & $31 \pm 2.8^{* *}$ & $0.20 \pm 0.01^{* *}$ \\
$1600 \mathrm{~T}+\mathrm{CCl}_{4}$ & $29 \pm 7^{* *}$ & $0.20 \pm 0.01^{* *}$ \\
\hline$* \mathrm{p} \leq 0.05$ v.s control group. & $* * \mathrm{p} \leq 0.05$ v.s $\mathrm{CCl}_{4}$ treated group
\end{tabular}

The volume of PC, GLOM, vessels and interstitial tissue were increased $80 \%, 150 \%, 83 \%$ and $64 \%(\mathrm{p} \leq$ 0.05 ), respectively in - treated mice compared to the controls (Tables III and IV). The volume of CD and LH did not show significant differences $(\mathrm{p}>0.05)$. Treatment with high dose $(1600 \mu \mathrm{g} / \mathrm{kg})$ of $T$. ammi significantly $(\mathrm{p} \leq 0.05)$ decreased the volume of PC and GLOM compared to the - treated group.

Effects of and T. ammi on glomerular number. The obtained results showed that glomerular numbers per kidney in treated group were significantly $(22.5 \%)$ lower than that of the control animals. Co-administration of $1600 \mu \mathrm{g} / \mathrm{kg} \mathrm{T}$. ammi and prevented the decrease of glomerular numbers significantly $(\mathrm{p} \leq 0.05)$ in comparison with the -treated group (Table IV).

Effects of and T. ammi on length of renal tubules and vessels. The length of $\mathrm{PC}$ and vessel increased $51 \%$ and 45 $\%$, respectively $(\mathrm{p} \leq 0.05)$ after administration. However, the increase in length of DC, CD and LH were not significant $(p>0.05)$ in -treated mice compared to the controls. High dose of T. ammi could significantly improve the length of PC and vessels toward normal values (Table V).

Effects ofand T. ammi on serum profile. Serum concentration of urea and creatinine are presented in Table VI. Concentration of urea and creatinine was increased significantly $(\mathrm{p} \leq 0.05)$ in serum with -induced nephrotoxicity as compared to the control group. Coadministration of and different doses of T. ammi significantly improved the changed levels of urea and creatinine causing a subsequent recovery towards normalization. However, there was no significant difference between different doses of T. ammi.

\section{DISCUSSION}

The present study showed the ameliorative potential of T. ammi essential oil against - induced acute nephrotoxicity through stereological assessments and serum profile analysis. It has been documented that renal cortex contains higher amounts of cytochrom P450 than other organs and this increase the affinity of kidney for. Hence, has been commonly used for acute renal failure induction in experimental animals (Ronis et al., 1998).

Although, renal functional impairment following treatment can be recognized by high serum levels of urea and creatinine (Ozturk et al., 2003), it should be noted that creatinine concentration is a more potent indicator as it increase in the initial stages of renal disease. Furthermore, increase in serum level of creatinine can lead to the structural damage of nephrons (Gilbert et al., 1989). In the study, administration of $(1 \mathrm{mg} / \mathrm{kg}$ body weight $)$ result in significant increase of serum urea and creatinine as it was previously reported by other studies (Ogeturk et al., 2005; Khan \& Ahmed, 2009; Khan \& Zehra, 2013; Sherkatolabbasieh et al., 2017). The increased level of serum urea and creatinine were significantly improved toward normal levels in the high dose $(1600 \mu \mathrm{g} / \mathrm{kg}$ T. ammi) treated group when compared with the only treated animals. Similar studies have been 
reported that various plant can improved -induced renal injury intoxication (Khan et al., 2010; Khan \& Siddique, 2012; Sherkatolabbasieh et al.). These results indicate protective effect of T. ammi against nephrotoxicity.

Our results showed that treated animals experienced noticeable renal hypertrophy which was mainly due to the cortical enlargement. Accordingly, proximal convoluted tubules and vessels were affected in respect of their volume and length. These alterations were alleviated significantly in the fifth group which received high dose of T. ammi.

In the present study, only treated mice showed glomerular hypertrophy. This event could be related to the vasoconstriction and congestion of capillary tufts in the renal corpuscles. Glomerular hypertrophy was prevented in high dose group in comparison with the only treated group. There are some reports that another plant extract such as Oxalis corniculata (Khan \& Zehra), Citharexylum spinosum (Khan $\&$ Siddique) and Sonchus asper (Khan et al., 2010) can inhibit glomerular hypertrophy induced through nephrotoxicity.

Another nephroprotective effect of T. ammi is its prevention of glomerular loss at high dose $(1600 \mu \mathrm{g} / \mathrm{kg})$. Embryologically, nephrogenesis stops after birth. Therefore, glomerular loss is a irreversible event. - induced nephrotoxicity has glomerular effect that can led to loss of filtration rate, mesangial cell proliferation and apoptosis (Tavifi \& Ahmadvand, 2011).

It is well established that induce Reactive Oxygen Species (ROS) which later can damage antioxidant barriers and start the process of lipid peroxidation (Halliwell \& Gutteridge, 2007). Therefore, use of certain plant extract rich in antioxidant agents can ameliorate toxicity. The results of GC/MS analysis showed that Tymol (44.2\%), p-Cymene (25.7 $\%$ ) and g-Terpinene $(25.1 \%)$ constitute the main components of T. ammi essential oil. Free radicals scavenging ability of these compounds were established previously. The antioxidant activity of Thymus marschallianus and Thymus proximus' essential oils which are mainly constituted by thymol, pcymene andg-terpinene have been examined earlier by safranin method (Jia et al., 2010). The activity of both essential oils were reported to be dose dependent which is consistent with the present results. Furthermore, antioxidant activity for essential oils of some other plants containing thymol, p-cymene andg-terpinene such as Thymus vulgaris, Salvia officinalis, Origanum vulgare (Viuda-Martos et al., 2010), Satureja intricate (Jordan et al., 2010) and Lavandula angustifolia (Yang et al., 2010) have been approved. Therefore, it may said that the nephroprotective activity of essential oil of T. ammi is attributed to the presence of thymol, p-cymene and $g$ terpinene.

\section{CONCLUSIONS.}

Based on the obtained results, essential oil of T. ammi at high dose ameliorated renal structural changes and serum biomarkers disturbance induced followingintoxication. Thymol, p-cymene,g-terpinene and other antioxidant contents may justify its nephroprotective and therapeutic properties. Therefore, T. ammi can be considered as a new nephroprotective agent against tocxicity.

\section{ACKNOWLEDGEMENTS.}

The authors are gratfull to Mr. Moradi for technical assisstance in essential oil preparation. The Kermanshah University of Medical Sciences is highly apprecieated for financial support.

FARZAEI, M. H.; ZANGENEH, M. M.; GOODARZI, N. \& ZANGENEH, A. Evaluación estereológica de los efectos nefroprotectores del aceite esencial de Trachyspermum ammi contra la nefrotoxicidad inducida por tetracloruro de carbono en ratones. Int. $J$. Morphol., 36(2):750-757, 2018.

RESUMEN: En la medicina popular se ha utilizado el aceite esencial de Trachyspermum ammi (T. ammi) como agente antiinflamatorio, antipirético, antibacteriano y anti fúngico. El presente estudio se realizó para investigar el efecto protector de Trachyspermum ammi (T. ammi) aceite esencial contra la nefrotoxicidad inducida en ratones. Treinta y cinco ratones fueron divididos en cinco grupos de la siguiente manera; el control positivo recibió $1 \mathrm{~mL} / \mathrm{kg} /$ ip de aceite de oliva, el control negativo recibió 1 $\mathrm{mg} / \mathrm{kg} / \mathrm{ip}+0,5 \mathrm{~mL}$ de agua destilada por vía oral y grupos de tratamiento arbóreo que recibieron un control similar al negativo y 200,800 y $1600 \mathrm{mg} / \mathrm{kg}$ de T. aceite esencial de $T$. ammi, respectivamente. Todos los tratamientos se realizaron dos veces por semana (sábado y miércoles) durante 45 días. En el último día de tratamiento, se tomaron muestras de sangre para evaluar la urea y la creatinina, y se extrajo el riñón izquierdo para realizar estimaciones estereológicas. El aceite esencial de T. ammi a dosis altas significativamente $(\mathrm{p} \leq 0,05)$ disminuyó los niveles séricos de creatinina y urea en comparación con el grupo tratado. El volumen total del riñón, la corteza, los túbulos contorneados proximales (PC), el glomérulo, los vasos y el tejido intersticial, así como la longitud total de la PC y el vaso aumentaron significativamente $(\mathrm{p} \leq 0,05)$ después de la administración y se restablecieron a niveles normales con dosis altas de T. ammi. Además, una dosis alta de T. ammi mejoró significativamente la pérdida glomerular $(\mathrm{p} \leq 0,05)$ en comparación con el grupo tratado. Debido a la composición química del aceite esencial de T. ammi como timol, $p$-cimeno, $\gamma$-terpineno con propiedades antioxidantes, se puede concluir que el aceite esencial de $T$. ammi puede mejorar la lesión renal inducida después de la toxicidad a través de sus componentes antioxidantes.

PALABRAS CLAVE: Trachyspermum ammi; Tetracloruro de carbono; Aceite esencial; Estereología; Riñón. 


\section{REFERENCES}

Adewole, S. O.; Salako, A. A.; Doherty, O. W. \& Naicker, T. Effect of melatonin on carbon tetrachloride-induced kidney injury in Wistar rats. Afr. J. Biomed. Res., 10:153-64, 2007.

Bera, D.; Lahiri, D. \& Nag, A. Novel natural antioxidant for stabilization of edible oil: The ajowan (Carum copticum) extract case. J. Am. Oil Chem. Soc., 81(2):169-72, 2004.

Dashti-Rahmatabadi, M. H.; Hejazian, S. H.; Morshedi, A. \& Rafati, A. The analgesic effect of Carum copticum extract and morphine on phasic pain in mice. J. Ethnopharmacol., 109(2):226-8, 2007.

Faramarzi, E.; Zangeneh, M. M.; Zangeneh, A. \& Moradi, R. Effect of Cinnamomum zelanicumon oil on hyponeophagia anxiety test in Balb C male mice. Online J. Vet. Res., 21(2):77-80, 2017.

Gilbert, D. N.; Wood, C. A.; Kohlepp, S. J.; Houghton, D. C.; Finkbeiner, H. C.; Lindsley, J. \& Bennett, W. M. Polyaspartic acid prevents experimental aminoglycoside nephrotoxicity. J. Infect. Dis., 159(5):945-53, 1989.

Gundersen, H. J.; Bendtsen, T. F.; Korbo, L.; Marcussen, N.; Møller, A.; Nielsen, K.; Nyengaard, J. R.; Pakkenberg, B.; Sørensen, F. B. \& Vesterby, A. Some new, simple and efficient stereological methods and their use in pathological research and diagnosis. APMIS, 96(5):379-94, 1988.

Halliwell, B. \& Gutteridge, J. M. Free Radicals in Biology and Medicine. $4^{\text {th }}$ ed. Oxford, Clarendon Press, 2017.

Hejazian, S. H.; Mosaddegh, M. H. \& Dashti Rahmatabadi, H. Antinociceptive effects of Carum copticum extract in mice using formalin test. World Appl. Sci. J., 3:215-9, 2008.

Javier Perez, A.; Courel, M.; Sobrado, J. \& Gonzalez, L. Acute renal failure after topical application of carbon tetrachloride. Lancet, 1(8531):515-6, 1987.

Jia, H. L.; Ji, Q. L.; Xing, S. L.; Zhang, P. H.; Zhu, G. L. \& Wang, X. H. Chemical composition and antioxidant, antimicrobial activities of the essential oils of Thymus marschallianus Will. and Thymus proximus Serg. J. Food Sci., 75(1):59-65, 2010.

Jordan, M. J.; Sanchez-Gomez, P.; Jimenez, J. F.; Quilez, M. \& Sotomayor, J. A. Chemical composition and antiradical activity of the essential oil from Satureja intricata, S. obovata; and their hybrid Datureja x delpozoi. Nat. Prod. Commun., 5:629-34, 2010.

Khan, M. R. \& Ahmed, D. Protective effects of Digera muricata (L.) Mart. on testis against oxidative stress of carbon tetrachloride in rat. Food. Chem. Toxicol., 47(6):1393-9, 2009.

Khan, M. R. \& Siddique, F. Antioxidant effects of Citharexylum spinosum in $\mathrm{CCl}$ ? induced nephrotoxicity in rat. Exp. Toxicol. Pathol., 64(4):349-55, 2012.

Khan, M. R. \& Zehra, H. Amelioration of $\mathrm{CCl}(4)$-induced nephrotoxicity by Oxalis corniculata in rat. Exp. Toxicol. Pathol., 65(3):327-34, 2013.

Khan, M. R.; Rizvi, W.; Khan, G. N.; Khan, R. A. \& Shaheen, S. Carbon tetrachloride-induced nephrotoxicity in rats: protective role of Digera muricata. J. Ethnopharmacol., 122(1):91-9, 2009.

Khan, R. A.; Khan, M. R.; Sahreen, S. \& Bokhari, J. Prevention of $\mathrm{CCl}_{4}$ induced nephrotoxicity with Sonchus asper in rat. Food Chem. Toxicol., 48(8-9):2469-76, 2010

Kumar, G.; Banu, G. S. \& Pandian, M. R. Evaluation of the antioxidant activity of Trianthema portulacastrum L. Indian J. Pharmacol., 37(5):331-3, 2005.

Mandarim-de-Lacerda, C. A. Stereological tools in biomedical research. An. Acad. Bras. Cienc., 75(4):469-86, 2003.

Manna, P.; Sinha, M. \& Sil, P. C. Aqueous extract of Terminalia arjuna prevents carbon tetrachloride induced hepatic and renal disorders. $B M C$ Complement. Altern. Med., 30(6):33, 2006.

Masuda, Y. Learning toxicology from carbon tetrachloride-induced hepatotoxicity. Yakugaku Zasshi, 126(10):885-99, 2006.

Miguel, M. G. Antioxidant and anti-inflammatory activities of essential oils: a short review. Molecules, 15(12):9252-87, 2010.

Musabayane, C. T. The effects of medicinal plants on renal function and blood pressure in diabetes mellitus. Cardiovasc. J. Afr., 23(8):462-8, 2012.

Nyengaard, J. R. Stereologic methods and their application in kidney research.
J. Am. Soc. Nephrol., 10(5):1100-23, 1999.

Ogeturk, M.; Kus, I.; Colakoglu, N.; Zararsiz, I.; Ilhan, N. \& Sarsilmaz, M. Caffeic acid phenethyl ester protects kidneys against carbon tetrachloride toxicity in rats. J. Ethnopharmacol., 97(2):273-80, 2005.

Ozturk, F.; Ucar, M.; Ozturk, I. C.; Vardi, N. \& Batcioglu, K. Carbon tetrachloride-induced nephrotoxicity and protective effect of betaine in Sprague-Dawley rats. Urology, 62(2):353-6, 2003.

Rasooli, I.; Fakoor, M. H.; Yadegarinia, D.; Gachkar, L.; Allameh, A. \& Rezaei, M. B. Antimycotoxigenic characteristics of Rosmarinus officinalis and Trachyspermum copticum L. essential oils. Int. J. Food Microbiol., 122 (12):135-9, 2008.

Rechnagel, R. O.; Glende, E. A. Jr.; Dolak, J. A. \& Waller, R. L. Mechanisms of carbon tetrachloride toxicity. Pharmacol. Ther, 43(1):139-54, 1989.

Ronis, M. J.; Huang, J.; Longo, V.; Tindberg, N.; Ingelman-Sundberg, M. \& Badger, T. M. Expression and distribution of cytochrome P450 enzymes in male rat kidney: effects of ethanol, acetone and dietary conditions. Biochem. Pharmacol., 55(2):123-9, 1998.

Satyanarayana, P. S.; Singh, D. \& Chopra, K. Quercetin, a bioflavonoid, protects against oxidative stress-related renal dysfunction by cyclosporine in rats. Methods Find. Exp. Clin. Pharmacol., 23(4):175-81, 2001.

Sherkatolabbasieh, H.; Hagh-Nazari, L.; Shafiezadeh, S.; Goodarzi, N.; Zangeneh, M. M. \& Zangeneh, A. Ameliorative effects of the ethanolic extract of Allium saralicum R.M. Fritsch on CCl4-induced nephrotoxicity in mice: A stereological examination. Arch. Biol. Sci., 69(3):535-43, 2017.

Tahvilian, R.; Moradi, R.; Hajialiani, M.; Zangeneh, M. M.; Zangeneh, A.; Yazdani, H. \& Zhale H. Chemical composition and screening of antibacterial activities of essential oil of Pistacia khinjuk against Bacillus subtilis (ATCC No. 21332). Ann. Trop. Med. Public Health, 10(5):115964, 2016.

Tavifi, M. \& Ahmadvand, H. Effect of rosmarinic acid on inhibition of gentamicin induced nephrotoxicity in rats. Tissue Cell, 43(6):392-7, 2011.

Thangam, C. \& Dhananjayan, R. Antiinflammatory potential of the seeds of Carum copticum Linn. Indian J. Pharmacol., 34:388-91, 2003.

Viuda-Martos, M.; Navajas, Y. R.; Zapata, E. S.; Fernández-López, J. \& PérezÁlvarez, J. A. Antioxidant activity of essential oils of five spice plants widely used in a Mediterranean diet. Flavour. Fragr. J., 25(1):13-9, 2010.

Wadikar, D. D. \& Premavalli, K. S. Ajowan (Trachyspermumammi) munch: A shelf stable ready-to-eat appetizer, its development and storage. Int. Food Res. J., 19(1):321-5, 2012.

Yang, S. A.; Jeon, S. K.; Lee, E. J.; Shim, E. H. \& Lee, I. S. Comparative study of the chemical composition and antioxidant activity of six essential oils and their components. Nat. Prod. Res., 24(2):140-51, 2010.

Zangeneh, M. M.; Tahvilian, R.; Najafi, F.; Zangeneh, A.; Souri, N.; MoeiniArya, M. \& Zhaleh, S. Evaluation of the in vitro antibacterial effect of the hydroalcoholic extract of Scrophularia striata. Int. J. Sci. Eng. Res., 7(10):1693-702, 2016.

Corresponding author:

Mohammad Mahdi Zangeneh

Pharmaceutical Sciences ResearchCenter

Faculty of Pharmacy

Kermanshah University of Medical Sciences

Kermanshah

IRAN

E-mail: m.mehdizangeneh@yahoo.com

Received: 27-09-2017

Accepted: 19-12-2017 